\title{
Anthropogenic and naturally-produced organobrominated compounds in marine mammals from Brazil
}

\author{
Paulo R. Dorneles ${ }^{\mathrm{a}, \mathrm{b}, *}$, José Lailson-Brito ${ }^{\mathrm{a}, \mathrm{b}}$, Alin C. Dirtu ${ }^{\mathrm{c}, \mathrm{d}}$, Liesbeth Weijs ${ }^{\mathrm{c}, \mathrm{e}}$, Alexandre F. Azevedo ${ }^{\mathrm{b}}$, \\ João P.M. Torres ${ }^{a}$, Olaf Malm ${ }^{a}$, Hugo Neels ${ }^{c}$, Ronny Blust ${ }^{\mathrm{e}}$, Krishna Das ${ }^{\mathrm{f}}$, Adrian Covaci ${ }^{\mathrm{c}, \mathrm{e}}$ \\ a Biophysics Institute, Rio de Janeiro Federal University (UFRJ), Rio de Janeiro, Brazil \\ ${ }^{\mathrm{b}}$ Aquatic Mammal and Bioindicator Laboratory (MAQUA), School of Oceanography, Rio de Janeiro State University (UERJ), Brazil \\ c Toxicological Centre, Department of Pharmaceutical Sciences, University of Antwerp, Belgium \\ ' Department of Chemistry, "Al. I. Cuza” University of Iassy, Romania \\ e Laboratory for Ecophysiology, Biochemistry and Toxicology, Department of Biology, University of Antwerp, Belgium \\ ${ }^{\mathrm{f}}$ Laboratory for Oceanology, MARE Centre, Liege University, Belgium
}

\section{A R T I C L E I N F O}

Article history:

Received 28 March 2009

Accepted 3 October 2009

Available online 27 October 2009

\section{Keywords}

Flame retardants

PBDEs

MeO-PBDEs

Dolphins

Brazil

\begin{abstract}
A B S T R A C T
Liver samples from 51 cetaceans, comprising 10 species, stranded between 1994 and 2006 in a highly industrialized and urbanized region in Southeast Brazil, were analyzed for polybrominated diphenyl ethers (PBDEs) and methoxylated-PBDEs (MeO-PBDEs). A concentration range of PBDEs (3-5960 ng/g lw) similar to that observed in Northern Hemisphere dolphins was found. MeO-PBDE concentrations in continental shelf (CS) dolphins from Brazil are among the highest detected to date in cetaceans (up to $250 \mu \mathrm{g} / \mathrm{g} \mathrm{lw}$ ). Higher $\Sigma \mathrm{MeO}-\mathrm{PBDE}$ concentrations were measured in CS and oceanic dolphins than in estuarine dolphins. The $\Sigma \mathrm{PBDE} / \mathrm{\Sigma} \mathrm{MeO}-\mathrm{PBDE}$ ratio varied significantly ranging from a mean value of 7.12 to 0.08 and 0.01 for estuarine, CS and oceanic species, respectively. A positive correlation was observed between $\Sigma$ PBDE and year of stranding of male estuarine dolphins (Sotalia guianensis), which suggests temporal variation in the exposure. Placental transfer of organobrominated compounds was also evidenced in S. guianensis.
\end{abstract}

(c) 2009 Elsevier Ltd. All rights reserved.

\section{Introduction}

Environmental contamination by polybrominated diphenyl ethers (PBDEs) has received considerable attention due to the lipophilic, bioaccumulative and persistent nature of these compounds as well as their widespread use as flame retardants (Tanabe, 2004). A variety of biological effects have been reported for PBDEs in mammals, such as influence on the homeostasis of steroid and thyroid hormones (Darnerud et al., 2001; Zhou et al., 2001), as well as immunotoxicity (Fowles et al., 1994).

Methoxylated polybrominated diphenyl ethers (MeO-PBDEs) have been evidenced in marine environments (Haglund et al., 1997), with the tetrabrominated 2'-MeO-BDE 68 and 6-MeO-BDE 47 being the most abundant (Vetter et al., 2002). However, several other MeO-PBDE

\footnotetext{
* Corresponding author. Instituto de Biofísica Carlos Chagas Filho; Centro de Ciências da Saúde; Universidade Federal do Rio de Janeiro; 21941-902, Rio de Janeiro, RJ, Brazil. Tel.: +55 21 25877133; fax: +55 2125877689 .

E-mail addresses: dorneles@biof.ufrj.br (P.R. Dorneles), lailson@uerj.br (J. Lailson-Brito), alin.dirtu@chem.uaic.ro (A.C. Dirtu), liesbeth.weijs@ua.ac.be (L. Weijs), azevedo.alex@uerj.br (A.F. Azevedo),jptorres@biof.ufrj.br (J.P.M. Torres), olaf@biof.ufrj.br (O. Malm), hugo.neels@ua.ac.be (H. Neels), ronny.blust@ua.ac.be (R. Blust), krishna.das@ulg.ac.be (K. Das), adrian.covaci@ua.ac.be (A.Covaci).
}

congeners, such as tribrominated and other tetrabrominated MeO-PBDEs, could be observed in samples of marine mammals (Melcher et al., 2005). MeO-PBDEs have been reported as having natural origin (Teuten et al., 2005; Teuten and Reddy, 2007), being formed by sponges (Vetter et al., 2002) or algae (Malmvärn et al., 2005). MeO-PBDEs have been detected in marine mammals at concentrations comparable to halogenated organic compounds of anthropogenic origin (Vetter et al., 2002; Vetter, 2006).

The Brazilian coastline has around $8500 \mathrm{~km}$ of length and Guanabara Bay, in Rio de Janeiro state, Southeast Brazilian region (Fig. 1), is the most anthropogenically disturbed area along the country shoreline (Azevedo et al., 2009). The estuary is bordered by 12000 industries and four cities (including Rio de Janeiro metropolitan area) with a total population of about 11 million people (Kjerfve et al., 1997). Despite the anthropogenic pressure, Guanabara Bay supplies food and breeding grounds for Guiana dolphins (Sotalia guianensis) (Azevedo et al., 2009; Cunha et al., 2005). The remaining nine delphinid species analyzed inhabit either the continental shelf (CS) or oceanic environments frontal to Guanabara Bay (Bastida et al., 2007).

Considering the demonstrated biomagnification capacity of organohalogen compounds (Muir et al., 2006; Van de Vijver et al., 2003; Voorspoels et al., 2003) analyses of cetacean tissues are of interest (Pangallo and Reddy, 2009). Therefore, the main objective of the present study was to use cetaceans as a source of information on organobrominated compound concentrations and profiles in top predators from 


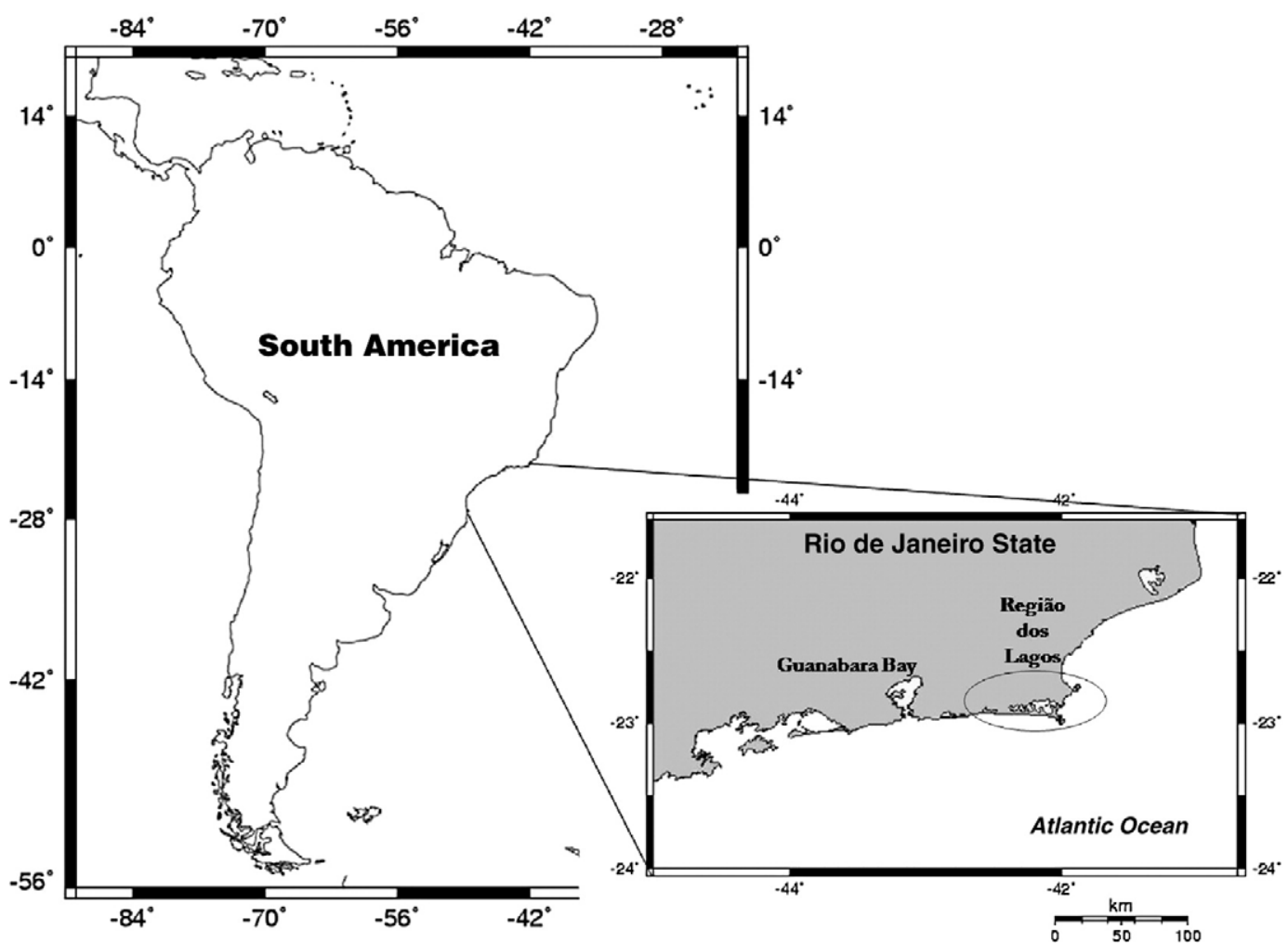

Fig. 1. South America map amplifying Rio de Janeiro State, as well as stressing Guanabara Bay and the "Região dos Lagos" area.

three environments (estuarine, CS and oceanic) distinctively distant from the source of environmental contamination. In order to generate information on the placental transfer of organobrominated compounds, fetus/mother ratios of hepatic concentrations of these compounds were calculated for two Guiana dolphin fetus-mother pairs. To the authors' knowledge, this is the first study to determine organobrominated compounds in tissues of marine mammals from the southwest Atlantic Ocean.

\section{Material and methods}

Liver samples were collected from 51 cetaceans stranded on the beaches of Rio de Janeiro state, in Southeast Brazil (Fig. 1), from 1994 to 2006. Sampled specimens comprised 10 delphinid species that occupy estuarine, CS and oceanic environments (Table 1). The classification of the cetacean species from Brazilian waters as estuarine, CS and oceanic delphinids was based on published information that comprises: (i) a systematic population study of $S$. guianensis performed using photoidentification techniques (Azevedo et al., 2004); (ii) stomach content analyses (Santos and Haimovici, 2001); (iii) geographically referenced opportunistic observation of dolphins (Moreno et al., 2005); and (iv) the use of cadmium for pointing out relative contributions of different potential sources to the diet of cetaceans, indicating the inshore versus offshore contribution to food intake (Dorneles et al., 2007a,b). Age was determined only for male Guiana dolphins and female Fraser's dolphins by counting the growth layer groups present in dentine and cementum of the teeth (Dietz et al., 1991).

The following PBDE-congeners (IUPAC numbers) were targeted for

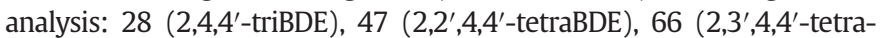

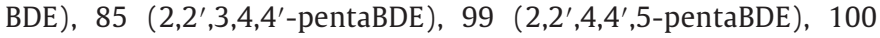

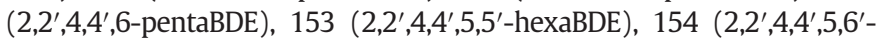
hexaBDE) and $183\left(2,2^{\prime}, 3^{\prime}, 4,4^{\prime}, 5,6^{\prime}\right.$-heptaBDE). Additionally, two

Table 1

Hepatic concentrations (ng/g, lipid wt.) of PBDEs and MeO-PBDEs in dolphins from Brazilian waters.

\begin{tabular}{|c|c|c|c|c|c|c|c|}
\hline \multirow[b]{2}{*}{ Habitat } & \multirow[b]{2}{*}{ Species } & \multirow[b]{2}{*}{$N$} & \multirow[b]{2}{*}{ Gender } & \multicolumn{2}{|l|}{$\Sigma$ PBDEs } & \multicolumn{2}{|l|}{ ¿MeO-PBDEs } \\
\hline & & & & Mean \pm SD & Range & Mean \pm SD & Range \\
\hline \multirow[t]{3}{*}{ Estuarine } & Sotalia guianensis & 13 & M & $670 \pm 430$ & $260-1620$ & $150 \pm 150$ & $38-480$ \\
\hline & & 6 & $\mathrm{~F}$ & $160 \pm 150$ & $13-450$ & $75 \pm 43$ & $26-160$ \\
\hline & & 1 & NB & 242 & & 33 & \\
\hline \multirow[t]{8}{*}{ C. Shelf } & Stenella frontalis & 6 & $\mathrm{M}$ & $1150 \pm 710$ & $360-2440$ & $19200 \pm 19400$ & $6330-55400$ \\
\hline & & 1 & $\mathrm{~F}$ & 96 & & 3100 & \\
\hline & Pseudorca crassidens & 2 & NB & 3600 & $1210-5960$ & 148700 & $48400-249000$ \\
\hline & Tursiops truncatus & 3 & M & $960 \pm 600$ & $270-1350$ & $19900 \pm 10900$ & $12500-32400$ \\
\hline & Steno bredanensis & 1 & M & 360 & & 3900 & \\
\hline & & 2 & $\mathrm{~F}$ & 1150 & $700-1600$ & 15200 & $4800-25500$ \\
\hline & Delphinus delphis & 1 & M & 240 & & 3700 & \\
\hline & & 1 & $\mathrm{~F}$ & 125 & & 2900 & \\
\hline \multirow[t]{5}{*}{ Ocean } & Stenella attenuata & 1 & M & 1215 & & 88200 & \\
\hline & Stenella longirostris & 1 & $\mathrm{~F}$ & 150 & & 38000 & \\
\hline & Stenella coeruleoalba & 1 & Unident. & 210 & & 6900 & \\
\hline & Lagenodelphis hosei & 2 & M & 22 & $15-28$ & 2310 & $1820-2800$ \\
\hline & & 7 & $\mathrm{~F}$ & $7 \pm 4$ & $3-14$ & $1000 \pm 660$ & $420-2180$ \\
\hline
\end{tabular}


methoxylated-PBDEs (2'-MeO-BDE 68 and 6-MeO-BDE 47) were also determined. Individual standards for PBDEs (Wellington Laboratories, Guelph, ON, Canada) were used for identification and quantification. BDE 77 was used as internal surrogate standard (IS) for tetra and pentaBDEs and for MeO-PBDEs, while BDE 128 was used as IS for hexa- and heptaBDEs. All solvents used for the analysis ( $n$-hexane, acetone, dichloromethane, iso-octane) were of pesticide-grade (Merck, Darmstadt, Germany). Anhydrous sodium sulfate and silica were washed with nhexane before use. Extraction thimbles were pre-extracted for $1 \mathrm{~h}$ with the extraction mixture used for the samples and dried at $100{ }^{\circ} \mathrm{C}$ for $1 \mathrm{~h}$.

The method used for the cleanup of samples has been previously described and validated (Covaci et al., 2002; Voorspoels et al., 2003), and is also presented here. Between 0.4 and $0.6 \mathrm{~g}$ of freeze-dried liver tissue was spiked with $25 \mathrm{ng}$ of each IS and extracted for $2 \mathrm{~h}$ by hot Soxhlet with $100 \mathrm{~mL}$ hexane/acetone $(3 / 1 ; v / v)$. After lipid determination (performed gravimetrically on an aliquot of the extract), the extract was cleaned-up on $8 \mathrm{~g}$ of acidified silica. After elution with $15 \mathrm{~mL}$ hexane and $10 \mathrm{~mL}$ dichloromethane, the cleaned extract was concentrated to $200 \mu \mathrm{L}$.

An Agilent 6890-5973 GC-MS, operated in electron capture negative ionization (ECNI) mode, was equipped with a $20 \mathrm{~m} \times 0.18 \mathrm{~mm} \times 0.20 \mu \mathrm{m}$ AT-5 capillary column (Alltech, Lokeren, Belgium). Methane was used as moderating gas and the ion source, quadrupole and interface temperatures were set at 250,150 and $300{ }^{\circ} \mathrm{C}$, respectively. The MS was used in the selected ion-monitoring (SIM) mode with ions $\mathrm{m} / \mathrm{z} 79$ and 81 monitored during the entire run. Dwell times were set at $40 \mathrm{~ms}$. One $\mu \mathrm{L}$ of the cleaned extract was injected in solvent vent mode (injector temperature: $90^{\circ} \mathrm{C}$, held for $0.05 \mathrm{~min}$, then with $700{ }^{\circ} \mathrm{C} / \mathrm{min}$ to $305^{\circ} \mathrm{C}$ and kept for $25 \mathrm{~min}$; vent flow was set at $75 \mathrm{~mL} / \mathrm{min}$ and, purge vent opened at $1.5 \mathrm{~min}$ ). Helium was used as carrier gas at constant flow $(0.8 \mathrm{~mL} / \mathrm{min})$. The temperature of the AT- 5 column was kept at $90{ }^{\circ} \mathrm{C}$ for $1.50 \mathrm{~min}$, then increased to $200{ }^{\circ} \mathrm{C}$ at a rate of $20^{\circ} \mathrm{C} / \mathrm{min}$, further increased to $300{ }^{\circ} \mathrm{C}$ at a rate of $5{ }^{\circ} \mathrm{C} / \mathrm{min}$, kept for $15 \mathrm{~min}$.

For confirmation of MeO-PBDEs and PBDEs, the extracts were also analyzed on a GC/MS operated in electron ionization (EI) mode and equipped with a $25 \mathrm{~m} \times 0.22 \mathrm{~mm} \times 0.25 \mu \mathrm{m}$ HT-8 capillary column (SGE, Zulte, Belgium). The ion source, quadrupole and interface temperatures were set at 230,150 and $300^{\circ} \mathrm{C}$, respectively. The mass spectrometer was used in SIM mode with the two most intense ions (typically from the molecular cluster) acquired for each homologue group or isomer. One $\mu \mathrm{L}$ of the extract was injected in cold pulsed splitless mode (injector temperature $90{ }^{\circ} \mathrm{C}(0.03 \mathrm{~min})$ then to $300{ }^{\circ} \mathrm{C}$ at $700{ }^{\circ} \mathrm{C} / \mathrm{min}$, pressure pulse $25 \mathrm{psi}$, pulse time $1.50 \mathrm{~min}$, splitless time $1.50 \mathrm{~min})$. Helium was used as carrier gas at constant flow ( $1 \mathrm{~mL} / \mathrm{min}$ ). The temperature of the HT- 8 column was kept at $90{ }^{\circ} \mathrm{C}$ for $1.50 \mathrm{~min}$, then increased to $180^{\circ} \mathrm{C}$ at a rate of $15^{\circ} \mathrm{C} / \mathrm{min}$, further increased to $280^{\circ} \mathrm{C}$ at a rate of $5^{\circ} \mathrm{C} / \mathrm{min}$ and finally raised to $300{ }^{\circ} \mathrm{C}$ at a rate of $40^{\circ} \mathrm{C} / \mathrm{min}$, holding for $20 \mathrm{~min}$.

Quality assurance and quality control were performed through the regular analysis of procedural blanks (Relative Standard Deviation RSD $<20 \%$ for 8 replicates) and a Standard Reference Material (SRM 1945, PBDEs in whale blubber), for which the obtained concentrations were within $10 \%$ compared to the certified values. Additionally, the method performance was assessed through successful participation to interlaboratory studies (PBDEs in marine mammals) organized by NIST (USA National Institute of Standards and Technology). Multi-level calibration curves in the linear response interval of the detector were created for the quantification and good correlation $\left(r^{2}>0.999\right)$ was achieved. The identification of organobrominated compounds was based on their relative retention times (RRTs) to the IS used for quantification, ion chromatograms and intensity ratios of the monitored ions for quantification. A deviation of the ion intensity ratios within $20 \%$ of the mean values of the calibration standards was considered acceptable. The mean value of each analyte in the procedural blanks was used for subtraction. After blank subtraction, the limit of quantification (LOQ) was set at $3 * \mathrm{SD}$ of the value obtained in the procedural blanks. Method LOQs ranged between 1 and $4 \mathrm{ng} / \mathrm{g}$ lipid weight (lw) for individual PBDE and MeOPBDE congeners.

Depending on data normality (Shapiro-Wilk's $W$ test), parametric (Student's t-test and Pearson's ( $r$ ) correlation test) or non-parametric tests (Mann-Whitney $U$ test and Spearman's (Rs) correlation test) were used. Due to the low number of individuals of some species, only data from Guiana dolphins, Atlantic spotted dolphins and Fraser's dolphins were included in statistical analyses.

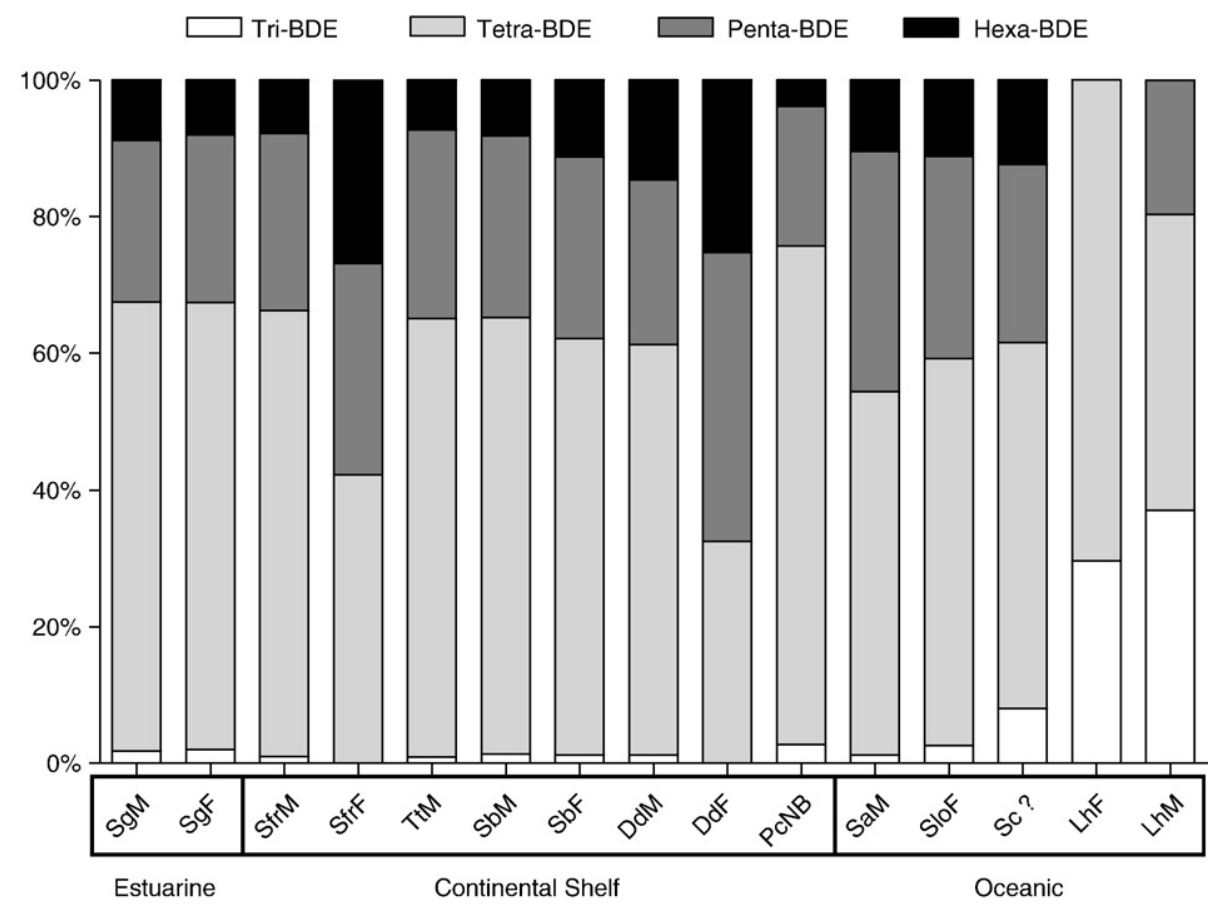

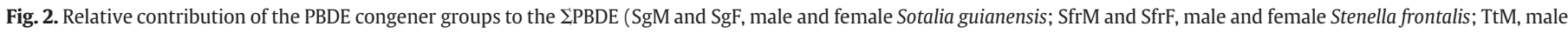

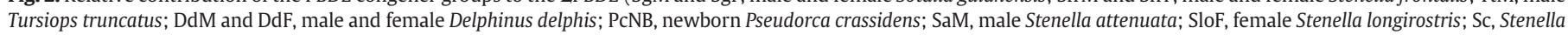
coeruleoalba of unidentified sex; LhM and LhF, male and female Lagenodelphis hosei). 


\section{Results and discussion}

\subsection{PBDES}

Among the analyzed PBDE congeners, BDE 183 could not be detected in any of the cetacean samples, which is probably a result of a combination of factors, such as low usage of octaBDE technical mixture in Brazil and debromination of BDE 183 to BDE 154 as observed in biota (Stapleton et al., 2004). These data corroborate information raised by Zhu and Hites (2003), since BDE 183 was not detected in mussels collected from Guanabara Bay, Rio de Janeiro state, in 1996. However, BDE 183 was detected in human breast adipose samples from Brazil (Kalantzi et al., 2009), which strengthens the possibility of debromination of the congener in the environment. Concentrations of PBDEs and MeO-PBDEs measured in the various delphinid species from the present study are given in Table 1. Covaci et al. (2002) reported a similar range of PBDEs (410 to $5810 \mathrm{ng} / \mathrm{g} \mathrm{lw}$ ) in liver samples from North Sea harbor porpoises (Phocoena phocoena). BDE 47 was the predominant PBDE congener in all dolphin species and it contributed by $32-80 \%$ to the $\Sigma$ PBDEs, except for the Fraser's dolphin, a delphinid species of extreme oceanic habit (Dorneles et al., 2008a). BDE 47 was the only PBDE congener detected in two out of the nine analyzed Fraser's dolphins. No significant differences were observed when comparing percentages of BDE 47 contribution to $\Sigma$ PBDEs between male Guiana dolphins and male Atlantic spotted dolphins $(p=0.42)$, between female Guiana dolphins and female Fraser's dolphins $(p=0.47)$ or between male and female Guiana dolphins $(p=0.92)$. For Guiana dolphins, the PBDE concentrations decreased in the following order BDE 47> BDE 100>BDE 99>BDE 154>BDE 153>BDE 28> BDE 85. The PBDE profile in this species differs from that in the oceanic Fraser's dolphin (Fig. 2). BDE 28, the only tribrominated PBDE determined, was the second most abundant congener in the Fraser's dolphins. BDE 66 was measured in delphinids living in CS and oceanic environments and it was not detected in the estuarine Guiana dolphins.

Debromination of BDE 99 to BDE 47 was demonstrated (Stapleton et al., 2004) and a model (Bhavsar et al., 2008) applied to experimental laboratory data (Tomy et al., 2004) indicated the occurrence of debromination of BDE 47 to BDE 28 (Bhavsar et al, 2008). Thus, the BDE 47/BDE 99 and BDE 28/BDE 47 ratios were calculated for each individual in the present study. There was no significant difference $(p=0.12)$ between male Guiana dolphins and Atlantic spotted dolphins of the same gender regarding the BDE 47/BDE 99 ratio, which could not be calculated for Fraser's dolphins since only one individual of the species presented detectable levels of BDE 99. Significant difference was found between the values of the BDE 28/BDE 47 ratio of Guiana dolphin and Fraser's dolphin, with higher values in the latter species $(p=0.0001, T=-7.11)$. These differences in the PBDE profiles among estuarine, CS and oceanic delphinids could be attributed to skewing of PBDEs in oceanic waters in favor of more volatile components; however, significantly higher values of the BDE 28/BDE 47 ratio were found in Guiana (estuarine) dolphin than in Atlantic spotted (continental shelf) dolphin ( $p=0.002, T=3.6$ ). This latter finding cannot be explained on the basis of the volatility of the congeners, since it shows an increased contribution of a tribrominated PBDE in relation to a tetrabrominated PBDE in the species that lives closer to the sources of contamination. It indicates that these dissimilarities could also be the consequence of differences in the speciesspecific metabolism for individual PBDE congeners by the species present in distinct food webs (Hakk and Letcher, 2003).

The presence of $\mathrm{BDE} 47,99$, and 100 in the livers of estuarine dolphins indicates the possible use of the pentaBDE mixture in Brazil. A similar congener distribution was reported in fish (Dodder et al., 2002) and marine mammals (Ikonomou and Addison, 2008) from North America, where the pentaBDE mixture has been extensively used (Dodder et al., 2002; Ikonomou and Addison, 2008).

\section{2. $\mathrm{MeO}-\mathrm{PBDES}\left(2^{\prime}-\mathrm{MeO}-\mathrm{BDE} 68\right.$ and 6-MeO-BDE 47)}

Although a greater number of sampled specimens from all over the world would be necessary for the achievement of strong conclusions on global distribution of naturallyproduced organobrominated compounds in cetaceans, to the authors' knowledge, the concentrations of MeO-PBDEs obtained for cetaceans from Brazilian waters are among the highest detected to date in marine mammals (Table 1). The highest hepatic concentration

\section{A}

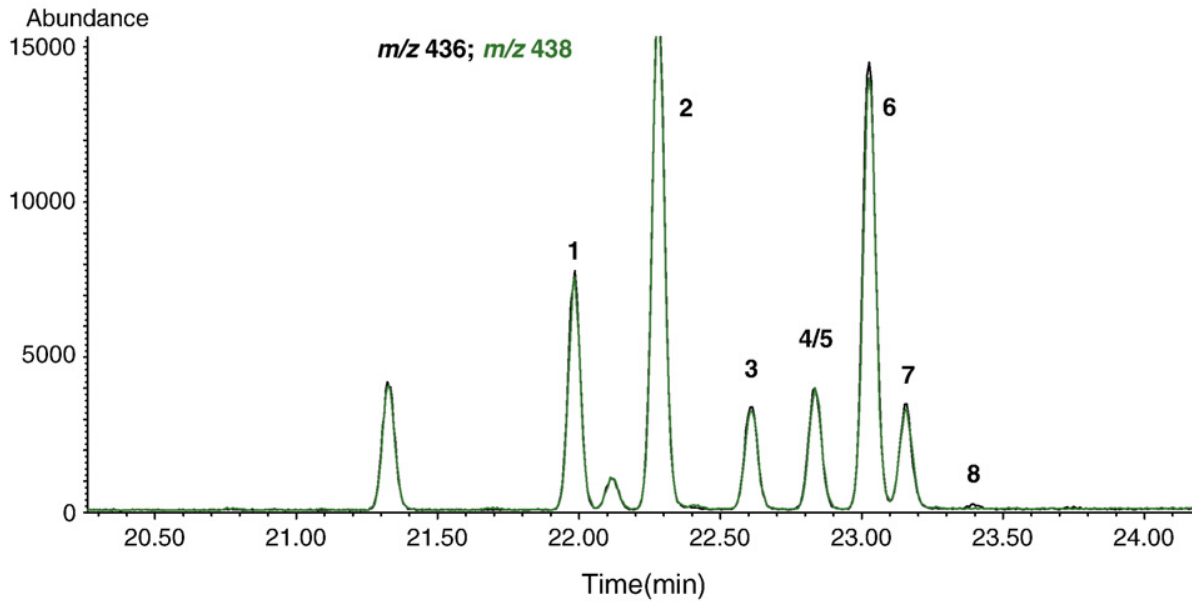

B

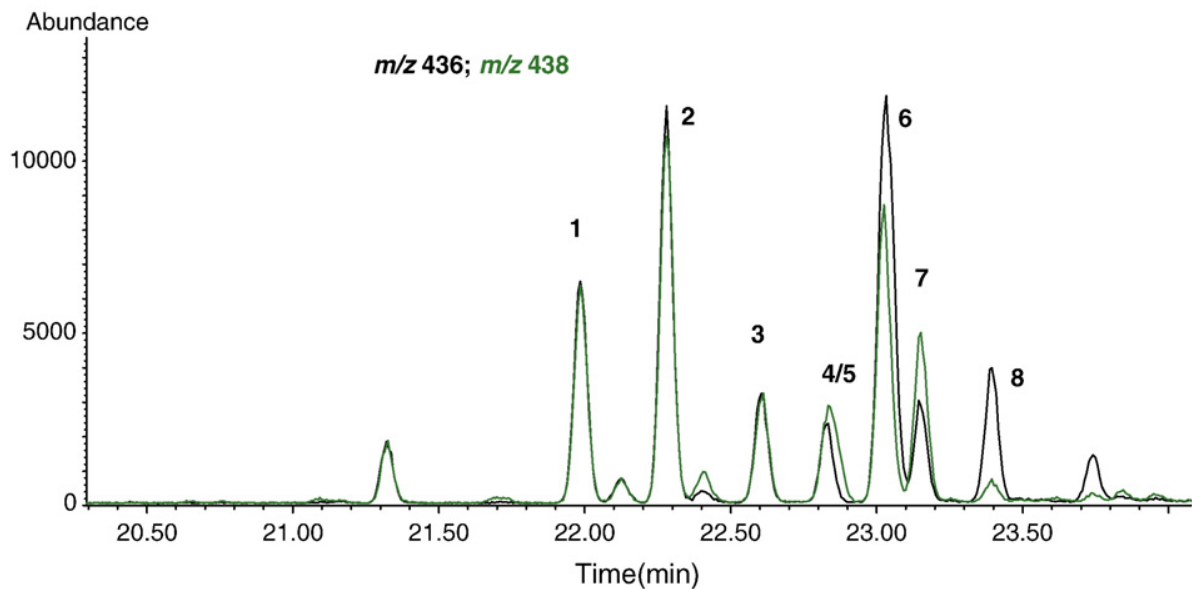

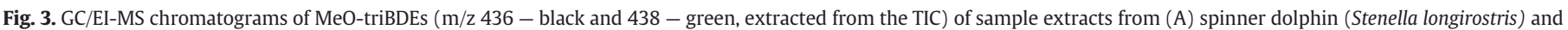
(B) false killer whale (Pseudorca crassidens). Numbers of peaks were assigned with increasing retention time and are similar to those assigned by Melcher et al. (2005). 

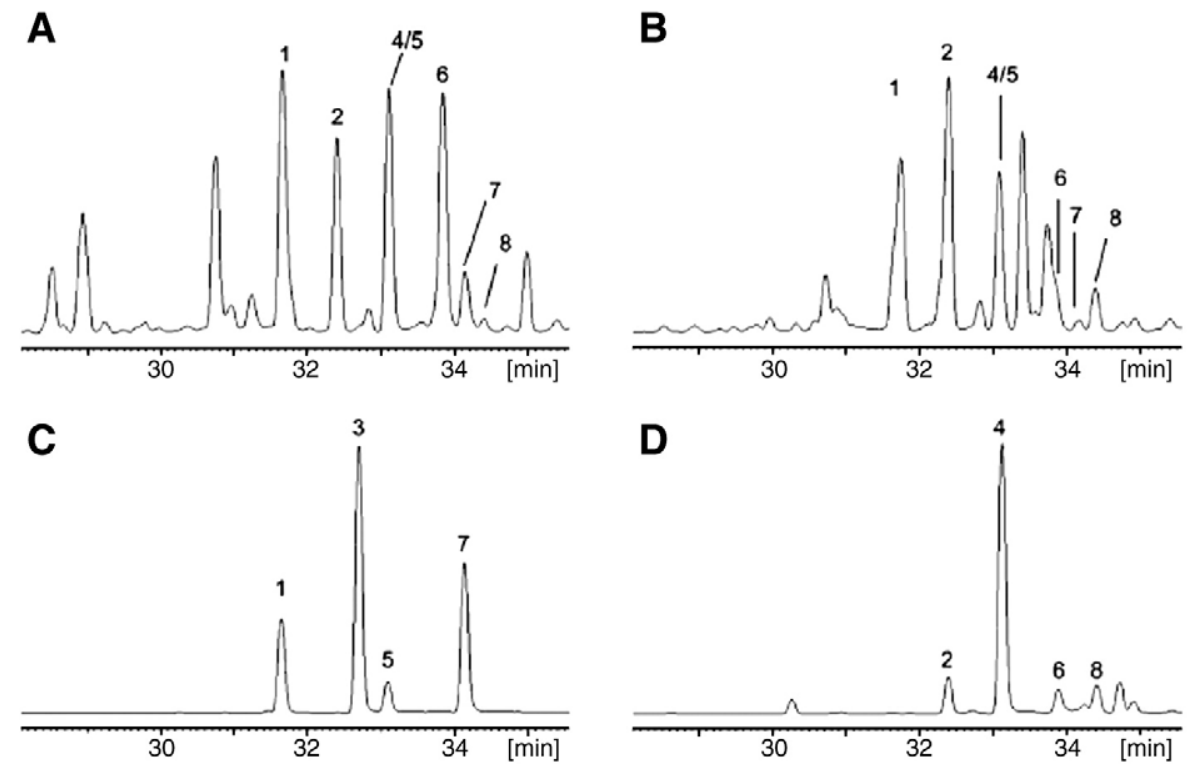

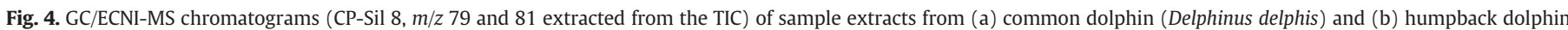

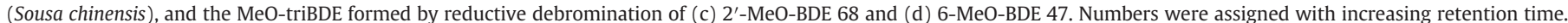
Reproduced with permission from Melcher et al. (2005).

observed among samples from 14 cetaceans of five different species from the Mediterranean Sea was $808 \mathrm{ng} / \mathrm{g}$ lw in a Risso's dolphin (Grampus griseus), considering the sum of three methoxylated tetrabromodiphenylethers ( $\mathrm{M}$ MeO-TeBDEs) (Pettersson et al., 2004). The highest concentration of 2'-MeO-BDE 68 previously reported for marine mammal tissues was $3760 \mathrm{ng} / \mathrm{g}$ wet weight found in the blubber of a pygmy sperm whale from Queensland, northeast Australia (Vetter et al., 2002). Blubber lipid percentage in marine mammals ranges between 30 and 90\% (Reijnders and Aguilar, 2002). Considering the lower bound lipid percentage (30\%) a maximum value of $12500 \mathrm{ng} / \mathrm{g}$ lipids can be calculated for 2'-MeO-BDE 68 in the pygmy sperm whale. The magnitude of the $\mathrm{MeO}$ PBDE concentrations measured in Brazilian cetaceans is indicated by the high number of dolphins $(N=8)$ in the present study which exceed this value. Significant higher $\Sigma \mathrm{MeO}$ PBDE concentrations were measured in male Atlantic spotted dolphins than in male Guiana dolphins $(p=0.0006, U=0)$. Similarly, higher concentrations of these compounds were determined in female Fraser's dolphin than in female Guiana dolphins $(p=0.006$ $T=-3.44$ ). Vetter (2006) raised the hypothesis that higher contributions of 2'-MeOBDE 68 are caused by sponges or associated organisms, whereas higher proportions of 6 $\mathrm{MeO}-\mathrm{BDE} 47$ are an indication of the presence of algae or associated organisms. Therefore, the ratio between these two naturally-produced organobrominated compounds ( 2 '-MeOBDE 68/6-MeO-BDE 47) was calculated for each individual in the present study. For male Guiana dolphins, this ratio had a mean value of $1.06(\mathrm{SD}=0.41)$ and ranged from 0.34 to 1.85. For male Atlantic spotted dolphins, values varying from 1.11 to 2.76 (mean $\pm \mathrm{SD}=1.86 \pm 0.75$ ) were found. For female Guiana dolphins, the mentioned ratio had a mean value of $1.45(\mathrm{SD}=0.72)$ and ranged from 0.81 to 2.52 . Regarding the oceanic Fraser's dolphin, the females had a mean value of $0.34(S D=0.26)$ and ranged from 0.16 to 0.81 . There was no significant difference between male and female Guiana dolphins $(p=0.14)$. Significant differences were observed while comparing ratios in two distinct scenarios, i.e., between male Guiana dolphins and male Atlantic spotted dolphins (higher values in the Atlantic spotted dolphins; $p=0.007, T=-3.07$ ), as well as between female Guiana dolphins and Fraser's dolphins of the same gender (higher values in the Guiana dolphins; $p=0.004, U=1$ ). According to Vetter (2006), this implies that CS delphinids such as Atlantic spotted dolphins, would be receiving MeO-BDEs predominantly from sponges, or associated organisms. MeO-PBDEs have been isolated from sponges of the genus Dysidea (Sharma and Vig, 1972) and the presence of these organisms has already been reported in the "Região dos Lagos" area (Oigman-Pszczol et al., 2004), in Rio de Janeiro state (Fig. 1), a region strongly influenced by the upwelling phenomenon (Costa and Fernandes, 1993). Interestingly, 11 out of the 17 delphinids that inhabit the CS were found in that area, while Guiana dolphins were found elsewhere, mostly in Guanabara Bay (16 out of 20 Guiana dolphins). Advection by upwelling is an example of a physical transport process with important implications in organic compound redistribution, especially for nektonic organisms (Lohmann et al., 2007). Therefore the hypothesis that the upwelling phenomenon may be contributing to the transport of MeO-PBDEs from the benthic to the pelagic food chain in the region should not be ruled out. Squids constitute important prey for the analyzed CS delphinids (Dorneles et al., 2007a) and "Região dos Lagos" is an area where these mollusks are particularly abundant (Costa and Haimovici,

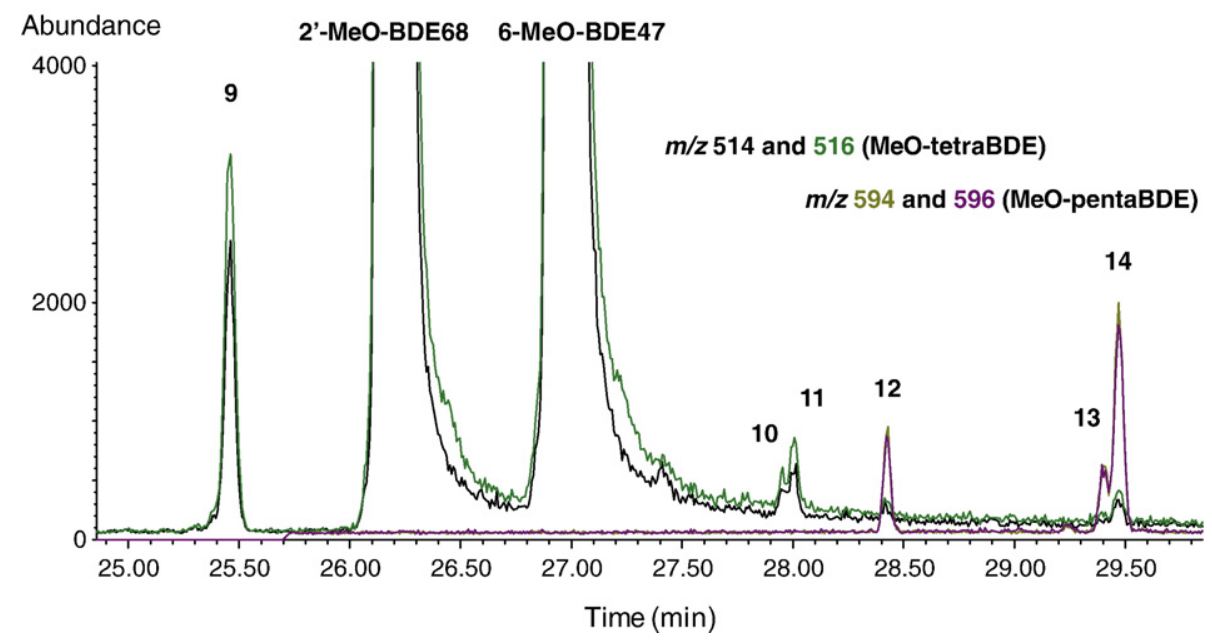

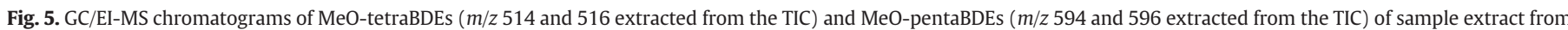
a false killer whale (Pseudorca crassidens). 
Table 2

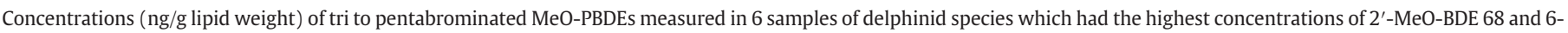
MeO-BDE 47.

\begin{tabular}{|c|c|c|c|c|c|c|c|c|c|c|}
\hline & Group & $\begin{array}{l}\mathrm{RT} \\
(\mathrm{min})\end{array}$ & Possible congener & $\begin{array}{l}\text { Congener used for } \\
\text { calculations }\end{array}$ & $\begin{array}{l}\text { Steno } \\
\text { bredanensis }\end{array}$ & $\begin{array}{l}\text { Stenella } \\
\text { frontalis (A) }\end{array}$ & $\begin{array}{l}\text { Stenella } \\
\text { frontalis (B) }\end{array}$ & $\begin{array}{l}\text { Stenella } \\
\text { longirostris }\end{array}$ & $\begin{array}{l}\text { Stenella } \\
\text { attenuata }\end{array}$ & $\begin{array}{l}\text { Pseudorca } \\
\text { crassidens }\end{array}$ \\
\hline 1 & MeO-triBDE & 21.98 & $?$ & 2'-MeO-BDE28 & 10 & 7 & 11 & 15 & 11 & 41 \\
\hline 2 & MeO-triBDE & 22.28 & 6-MeO-BDE1 $7^{\mathrm{a}}$ & 2'-MeO-BDE28 & 20 & 16 & 32 & 35 & 47 & 70 \\
\hline 3 & MeO-triBDE & 22.61 & $?$ & 2'-MeO-BDE28 & $<4$ & $<4$ & 5 & 7 & 4 & 21 \\
\hline $4 / 5$ & $\mathrm{MeO}$-triBDE & 22.83 & $\begin{array}{l}\text { 6'-MeO-BDE17/2- } \\
\text { MeO-BDE39 }\end{array}$ & 2'-MeO-BDE28 & 4 & 4 & 6 & 8 & 11 & 24 \\
\hline 6 & MeO-triBDE & 23.03 & 6-MeO-BDE28 ${ }^{\mathrm{a}}$ & 2'-MeO-BDE28 & 11 & 8 & 13 & 31 & 15 & 58 \\
\hline 7 & MeO-triBDE & 23.16 & $?$ & 2'-MeO-BDE28 & $<4$ & $<4$ & 5 & 7 & 5 & 32 \\
\hline 8 & $\mathrm{MeO}$-triBDE & 23.39 & $2^{\prime}-\mathrm{MeO}-\mathrm{BDE} 28^{\mathrm{a}}$ & 2'-MeO-BDE28 & $<4$ & $<4$ & $<4$ & 4 & 6 & 13 \\
\hline Sum MeO-triBDEs & & & & & 45 & 35 & 72 & 107 & 99 & 259 \\
\hline 9 & MeO-tetraBDE & 25.44 & 6-MeO-BDE49 & 6-MeO-BDE47 & 12 & 13 & 3 & 6 & 22 & 65 \\
\hline 10 & MeO-tetraBDE & 27.91 & 5-MeO-BDE47 & 5-MeO-BDE47 & $<3$ & $<3$ & $<3$ & $<3$ & $<3$ & 3 \\
\hline 11 & MeO-tetraBDE & 27.97 & 4-MeO-BDE49 & 4-MeO-BDE49 & 3 & $<3$ & $<3$ & 3 & 4 & 10 \\
\hline Sum MeO-tetraBDEs & & & & & 15 & 13 & 3 & 9 & 26 & 78 \\
\hline 12 & MeO-pentaBDE & 28.39 & $?$ & 6-MeO-BDE99 & 6 & 14 & 6 & $<3$ & 3 & 29 \\
\hline 13 & MeO-pentaBDE & 29.39 & 6-MeO-BDE90 & 6-MeO-BDE99 & $<3$ & $<3$ & 5 & $<3$ & 3 & 20 \\
\hline 14 & MeO-pentaBDE & 29.46 & 6-MeO-BDE99 & 6-MeO-BDE99 & 6 & 20 & 31 & $<3$ & 20 & 78 \\
\hline Sum MeO-pentaBDEs & & & & & 12 & 34 & 42 & $<3$ & 26 & 127 \\
\hline $\begin{array}{l}\text { Sum } \\
\text { MeO-tri-pentaBDEs } \\
(1-14)\end{array}$ & & & & & 72 & 82 & 117 & 116 & 152 & 464 \\
\hline 2'-MeO-BDE68 & MeO-tetraBDE & 26.20 & & 2'-MeO-BDE68 & 15000 & 19000 & 39900 & 25400 & 68500 & 158000 \\
\hline 6-MeO-BDE47 & $\mathrm{MeO}$-tetraBDE & 26.95 & & 6-MeO-BDE47 & 10500 & 8500 & 15500 & 12600 & 19800 & 90900 \\
\hline Sum 2MeO-tetraBDEs & & & & & 25500 & 27500 & 55400 & 38000 & 88300 & 248900 \\
\hline $\begin{array}{l}\text { Sum } 1-14 / \text { Sum } \\
\text { 2MeO-tetraBDEs (\%) }\end{array}$ & & & & & 0.31 & 0.33 & 0.21 & 0.32 & 0.17 & 0.19 \\
\hline
\end{tabular}

The MeO-triBDEs were numbered according to Melcher et al. (2005). ${ }^{a}$ As suggested by Melcher et al. (2005).

1990). Since these nektonic invertebrates execute vertical diel migrations (Moiseev, 1991), they may also play a role on the benthic-pelagic transportation of MeO-PBDEs and hence contribute to the high concentrations found in the present study. The fact that the highest concentrations reported for cetaceans were found in samples from Queensland, Australia $\left(\sim 19^{\circ} \mathrm{S}\right)$ (Vetter et al., 2002$)$ and Rio de Janeiro state, Brazil $\left(\sim 22^{\circ} \mathrm{S}\right)$ draws attention to a possible more intense biosynthesis of MeO-PBDEs and/or bioavailability to nektonic organisms in tropical areas of the globe.

\subsection{Other MeO-PBDE congeners}

The GC/EI-MS screening of the Brazilian samples suggested the presence of several potential tribrominated $\mathrm{MeO}-\mathrm{PBDEs}$ compounds eluting prior to $2^{\prime}-\mathrm{MeO}-\mathrm{BDE} 68$. The profile of MeO-triBDEs observed in the dolphin species from Brazil (Fig. 3) agrees with the pattern observed in dolphin samples from Australia (Melcher et al., 2005, Fig. 4). As suggested by Melcher et al. (2005), the mixture of MeO-triBDEs congeners observed in the dolphin samples possibly derive from the debromination of 2'-MeO-BDE 68 and 6$\mathrm{MeO}-\mathrm{BDE}$ 47. However, intensities and profiles of the MeO-PBDE congeners observed in the dolphins may differ from those observed from the anaerobic debromination of 2 'MeO-BDE 68 and 6-MeO-BDE 47. Concentrations of the sum of MeO-triBDEs were relatively low, with the maximum value ( $260 \mathrm{ng} / \mathrm{g} \mathrm{lw}$ ) determined in a false killer whale (Pseudorca crassidens), which contained also the highest concentrations of 2'-MeO-BDE 68 and 6-MeO-BDE 47 (sum $250 \mu \mathrm{g} / \mathrm{g} \mathrm{lw}$ ). Besides the MeO-triBDE congeners, several $\mathrm{MeO}$-tetraBDE and MeO-pentaBDE congeners could also be detected (Fig. 5 and Table 2) and their identification was based on their elution order and pattern as compared to the work of Athanasiadou et al. (2006). Concentrations of these congeners were even lower than of MeO-triBDE congeners (Table 2). Interestingly, the sum of all MeO-PBDEs except 2'-MeO-BDE 68 and 6-MeO-BDE 47 made up a relatively constant percentage (between 0.17 and $0.33 \%$ ) to the sum of $2^{\prime}$-MeO-BDE 68 and 6-MeO-BDE 47.

3.4. Comparison between organobrominated compounds of natural and anthropogenic origin

A clear shift in the contribution of naturally-produced MeO-PBDEs and anthropogenic PBDEs to the sum of organobrominated compounds was observed between estuarine and CS dolphins (Fig. 6). For the Guiana dolphins, the ratio 2 PBDEs/乏MeO-PBDEs had a mean value of 7.12 ( $S D=8.31$ ) and ranged from 0.23 to 29.4 , while the ratio ranged from 0.02 to 0.16 (mean $\pm \mathrm{SD}=0.08 \pm 0.06$ ) for the Atlantic spotted dolphin and was 0.01 for the oceanic Fraser's dolphins.

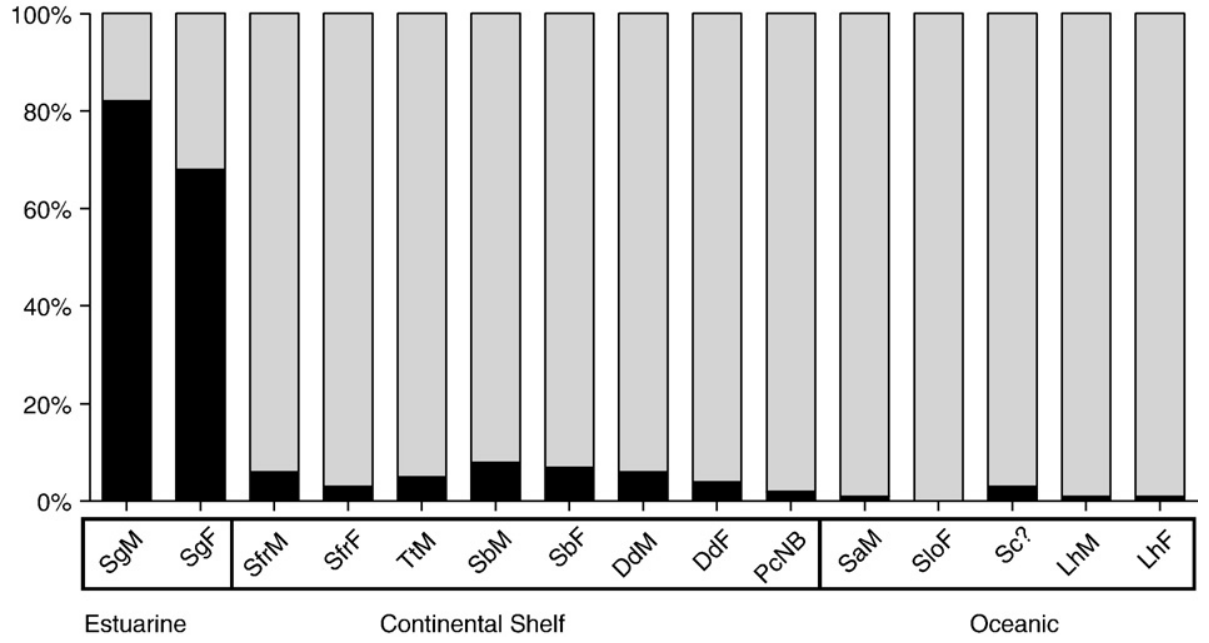

Fig. 6. Contribution of natural (light grey) and anthropogenic (black) PBDEs to the $\mathrm{PPBDE}$. Codes are given in Fig. 2. 


\subsection{Organobrominated compounds and dolphin age}

No correlation was found between $\Sigma$ PBDE concentrations and the age of male Guiana dolphins $(p=0.997)$. A positive correlation was observed between $\Sigma$ PBDE concentrations and the year of stranding $(p=0.002, R s=0.75)$, suggesting a temporal variation (from 1994 to 2006) in Guiana dolphin exposure, which may have hampered the existence of an age-related correlation. Total PBDE levels have increased exponentially in many biological matrices from all over the world, including samples from marine mammals, from the 1970s up to the beginning of the 2000s (Hites, 2004), which probably reflected an worldwide increase in the usage of PBDEs in consumer products as flame retardants during that period of time. However, there is also information on contrary, since no significant temporal trend was observed for PBDE levels in blubber samples from male California sea lions (Zalophus californianus) stranded between 1993 and 2003 (Stapleton et al., 2006). Considering specifically the post-2000 period, declines in PBDE concentrations have been reported for different biological matrices since the recent ban on the Octa- and pentaBDE technical formulations in Europe (Law et al., 2008). Regarding North America, a recent review article has drawn attention to the fact that investigations on PBDE levels in environmental matrices has shown either temporal increase or no time trend, emphasizing that a temporal decrease in PBDE concentrations was not verified in that part of the globe (Yogui and Sericano, 2009). Although the positive correlation between $\mathrm{PPBDE}$ concentrations and the year of stranding observed in the present study constitutes just a suggestion of temporal variation, it strengthens the need for temporal trend investigations in Brazil, especially considering the absence of legal restrictions on the use of PBDEs in the country. Regarding $\Sigma \mathrm{MeO}-\mathrm{PBDEs}$, there was no correlation between concentrations and the year of stranding $(p=0.84)$ of male Guiana dolphins.

Significant negative correlations were found between organobromines and the age of female Fraser's dolphins for both $\Sigma$ PBDEs $(p=0.005, r=-0.94)$ and $\Sigma$ MeO-PBDEs $(p=0.006, r=-0.94)$. Occurrence of decreasing concentrations of organohalogens with age has already been demonstrated in female cetaceans (Thron et al., 2004), which is a consequence of transplacental and lactational transfer of lipophilic organic compounds to the offspring, as older females are assumed to have gone through a greater number of pregnancies (O'Shea and Tanabe, 2003).

\subsection{Transplacental transfer of organobromines}

The fetus/mother ratios were calculated for two Guiana dolphin pairs, generating the values of 0.36 and 1.00 for BDE 28, 0.45 and 0.91 for BDE 47, 0.40 in both fetusmother pairs for 2'-MeO-BDE 68, 0.47 and 0.48 for 6-MeO-BDE 47, 0.29 and 0.50 for BDE $100,0.30$ and 0.60 for BDE 99, 0.17 and 0.50 for BDE 154 and 0.17 for BDE 153 (concentration of BDE 153 was below LOQ in one of the fetuses). These ratios compare favorably with Law et al. (2002), who found ratios of 0.78 for BDE 47 and 0.49 for BDE 99 in blubber of a harbor porpoise fetus-mother pair. Apparently, lower ratios and therefore reduced transplacental transfer were found for higher brominated compounds. This could be due to increased $K_{\mathrm{ow}}$ values and molecular sizes (Ikonomou and Addison, 2008). Both factors influence the movement of lipophilic compounds from the mother's lipid storage sites into the mother's blood, thereby indirectly influencing transplacental transfer. Differences between both fetus-mother pairs in the present study are possibly due to a combination of factors, such as the number of previous pregnancies, the age of the mother, and stage of development of the fetus. Because of the maternal transfer, male and female Guiana dolphins differed significantly in $\Sigma$ PBDE concentrations ( $p=0.003, U=5)$, but not in $\Sigma \mathrm{MeO}-\mathrm{PBDE}$ concentrations $(p=0.661$ ). Although there is contradictory information (Dietz et al., 2007), the occurrence of higher concentrations of lipophilic organohalogen compounds in males than in females is a common finding in aquatic mammals (Cleemann et al., 2000; Dietz et al., 2004; Kajiwara et al., 2008; Sonne et al., 2004).

\section{Conclusions}

The fact that the concentration range of anthropogenic PBDEs is similar in delphinids from Brazil to that determined in cetaceans from coastal waters of developed countries demonstrates the high exposure of marine top predators to PBDEs in Southeast Brazil. This generates concerns about the conservation of these cetacean populations, considering the toxicity of these pollutants. Additional apprehension is raised if the possibility of occurrence of synergistic effects among different persistent bioaccumulative toxicants is taken into account, since the cetacean populations considered herewith are highly exposed to organotins (Dorneles et al., 2008a), perfluorooctane sulfonate (Dorneles et al., 2008b), polychlorinated biphenyls and organochlorinated pesticides (Torres et al., 2006).

Considering the different pattern observed between estuarine and continental shelf dolphins regarding the contribution of MeO-PBDEs and PBDEs to the sum of organobrominated compounds, the possibility of using the $\Sigma \mathrm{PBDE} / \mathrm{MMeO}-\mathrm{PBDE}$ ratio as an indication of inshore versus offshore contribution to food intake should be investigated in other areas of the globe. This possibility is also supported by the fact that, concerning many odontocete cetaceans, it has been demonstrated a residence pattern in relatively small areas during the whole year (Bjørge, 2001).

\section{Acknowledgments}

This work was supported by the Ministry of Education of Brazil CAPES (fellowship to P.R. Dorneles, "Sandwich Programme" - PDEE), by the Brazilian Research Council - CNPq and by Rio de Janeiro State Government Research Agency - FAPERJ ("Pensa Rio" Program). José Lailson-Brito is a researcher of "Prociência" Program - FAPERJ/UERJ. Alexandre F. Azevedo has a research grant from CNPq (grant No. 304826/2008-1). Liesbeth Weijs acknowledges financial support from the IWT-Flanders. Adrian Covaci is financially supported by a postdoctoral fellowship from the FWO - Flanders. Krishna Das is FRS-FNRS Research Associate. João P. M. Torres is Advance Selikoff Fellow of the Mount Sinai School of Medicine (NY) and is funded in part by Grant No.: 1D43TW00640 from the Fogarty International Center of the National Institutes of Health. This is a MARE publication 179.

\section{References}

Athanasiadou M, Marsh G, Athanassiadis I, Asplund L, Bergman A. Gas chromatography and mass spectrometry of methoxylated polybrominated diphenyl ethers (MeO-PBDEs). J Mass Spectrom 2006;41:790-801.

Azevedo AF, Lailson-Brito J, Cunha HA, Van Sluys M. A note on site fidelity of marine tucuxis (Sotalia fluviatilis) in Guanabara Bay, southeastern Brazil. J Cetacean Res Manag 2004;6: 265-8.

Azevedo AF, Lailson-Brito J, Dorneles PR, Van Sluys M, Cunha HA, Fragoso ABL. Humaninduced injuries to marine tucuxis (Sotalia guianensis) (Cetacea: Delphinidae) in Brazil. Mar Biodivers Rec 2009;2:e22.

Bastida R, Rodríguez D, Secchi ER, da Silva VMF. In: Mamíferos Acuáticos de Sudamérica y Antártida 2007. Buenos Aires: Vasquez Mazzini Editores; 2007.

Bhavsar SP, Gandhi N, Gewurtz SB, Tomy G. Fate of PBDEs in juvenile lake trout estimated using a dynamic multichemical fish model. Environ Sci Technol 2008;42:3724-31.

Bjørge A. How persistent are marine mammal habitats in an ocean of variability? Habitat use, home range and site fidelity in marine mammals. In: Evans PGH, Raga JA, editors. Marine Mammals. Biology and Conservation. Kluwer Academic / Plenum Publishers; 2001.

Cleemann M, Riget F, Paulsen GB, de Boer J, Dietz R. Organochlorines in Greenland ringed seals (Phoca hispida). Sci Total Environ 2000;245:103-16.

Costa PAS, Fernandes FC. Seasonal and spatial changes in cephalopods caught in the Cabo Frio (Brazil) upwelling ecosystem. Bull Mar Sci 1993;52:751-9.

Costa PAS, Haimovici M. A pesca de polvos e lulas no litoral do Rio de Janeiro. Ciênc Cult 1990;42:1124-30.

Covaci A, Van de Vijver I, DeCoen W, Das K, Bouquegneau JM, Blust R, Schepens P. Determination of organohalogenated contaminants in liver of harbour porpoises (Phocoena phocoena) stranded on the Belgian North Sea coast. Mar Pollut Bull 2002;44:1152-69.

Cunha HA da Silva VMF, Lailson-Brito J, Santos MCO, Flores PAC, Martin AR, Azevedo AF, Fragoso ABL, Zanelatto RC, Solé-Cava AM. Riverine and marine ecotypes of Sotalia dolphins are different species. Mar Biol 2005;148:449-57.

Darnerud PO, Eriksen GS, Johannesson T, Laresen PB, Viluksela M. Polybrominated dipheny ethers: occurrence, dietary exposure, and toxicology. Environ Health Perspect 2001;109: 49-68.

Dietz R, Heide-Jørgensen MP, Teilmann J, Valentin N, Härkönen T. Age determination in European harbor seals Phoca vitulina. Sarsia 1991;76:17-21.

Dietz R, Rigét FF, Sonne C, Letcher R, Born EW, Muir DCG. Seasonal and temporal trends in polychlorinated biphenyls and organochlorine pesticides in East Greenland pola bears (Ursus maritimus), 1990-2001. Sci Total Environ 2004;331:107-24.

Dietz R, Rigét F, Sonne C, Letcher RJ, Backus S, Born EW, Kirkegaard M, Muir DCG. Age and seasonal variability of polybrominated diphenyl ethers in free-ranging East Greenland polar bears (Ursus maritimus). Environ Pollut 2007;146:166-73.

Dodder NG, Strandberg B, Hites RA. concentrations and spatial variations of polybrominated diphenyl ethers and several organochlorine compounds in fishes from the Northeastern United States. Environ Sci Technol 2002;36:146-51.

Dorneles PR, Lailson-Brito J, Santos RA, Costa PAS, Malm O, Azevedo AF, Torres JPM. Cephalopods and cetaceans as indicators of offshore bioavailability of cadmium off Central South Brazil Bight. Environ Pollut 2007a;148:352-9.

Dorneles PR, Lailson-Brito Jr J, Secchi ER, Bassoi M, Lozinski CPC, Torres JPM, Malm O. Cadmium concentrations in franciscana dolphin (Pontoporia blainvillei) from south Brazilian coast. Braz J Oceanogr 2007b;55:179-86.

Dorneles PR, Lailson-Brito J, Fernandez MAS, Vidal LG, Barbosa LA, Azevedo AF, Fragoso ABL Torres JPM, Malm O. Evaluation of cetacean exposure to organotin compounds in Brazilian waters through hepatic total tin concentrations. Environ Pollut 2008a;156: 1268-76.

Dorneles PR, Lailson-Brito J, Azevedo AF, Meyer J, Vidal LG, Fragoso ABL, Torres JPM, Malm O, Blust R, Das K. High accumulation of perfluorooctane sulfonate (PFOS) in 
marine tucuxi dolphins (Sotalia guianensis) from Brazilian coast. Environ Sci Technol 2008b;42:5368-73.

Fowles JR, Fairbrother A, Baecher-Steppan L, Kerkvliet NI. Immunologic and endocrine effects of the flame retardant pentabromodiphenyl ether (DE- 71) in C57BL/6J mice. Toxicology 1994;86:49-61.

Haglund PS, Zook DR, Buser HR, Hu J. Identification and quantification of polybrominated diphenyl ethers and methoxy-polybrominated diphenyl ethers in Baltic biota. Environ Sci Technol 1997;31:3281-7.

Hakk H, Letcher RJ. Metabolism in the toxicokinetics and fate of brominated flame retardants - a review. Environ Int 2003;29:801-28.

Hites RA. Polybrominated diphenyl ethers in the environment and in people: a metaanalysis of concentrations. Environ Sci Technol 2004;38:945-56.

Ikonomou MG, Addison RF. Polybrominated diphenyl ethers (PBDEs) in seal populations from eastern and western Canada: an assessment of the processes and factors controlling PBDE distribution in seals. Mar Environ Res 2008;66:225-30.

Kajiwara N, Kamikawa S, Amano M, Hayano A, Yamada TK, Miyazaki N, Tanabe S. Polybrominated diphenyl ethers (PBDEs) and organochlorines in melon-headed whales, Peponocephala electra, mass stranded along the Japanese coasts: maternal transfer and temporal trend. Environ Pollut 2008;156:106-14.

Kalantzi OI, Brown FR, Caleffi M, Goth-Goldstein R, Petreas M. Polybrominated diphenyl ethers and polychlorinated biphenyls in human breast adipose samples from Brazil. Environ Int 2009;35:113-7.

Kjerfve B, Ribeiro CHA, Dias GTH, Fillipo AM, Quaresma VS. Oceanographic characteristics of an impacted coastal bay: Baía de Guanabara, Rio de Janeiro, Brazil. Cont Shelf Res 1997;17: 1609-43.

Law RJ, Allchin CR, Bennett ME, Morris S, Rogan E. Polybrominated diphenyl ethers in two species of marine top predators from England and Wales. Chemosphere 2002;46: 673-81.

Law RJ, Herzke D, Harrad S, Morris S, Bersuder P, Allchin CR. Levels and trends of HBCD and BDEs in the European and Asian environments, with some information for other BFRs. Chemosphere 2008;73:223-41.

Lohmann R, Breivik K, Dachs J, Muir D. Global fate of POPs: current and future research directions. Environ Pollut 2007:150:150-65.

Malmvärn A, Marsh G, Kautsky L, Athanasidou M, Bergman A, Asplund L. Hydroxylated and methoxylated brominated diphenyl ethers in the red algae Ceramium tenuicorne and blue mussels from the Baltic Sea. Environ Sci Technol 2005;39:2990-7.

Melcher J, Olbrich D, Marsh G, Nikiforov V, Gaus C, Gaul S, Vetter W. Tetra- and tribromophenoxyanisoles in marine samples from Oceania. Environ Sci Technol 2005;39: 7784-9.

Moiseev SI. Observation of the vertical distribution and behaviour of nektonic squids using manned submersibles. Bull Mar Sci 1991;49:446-56.

Moreno IB, Zerbini AN, Danilewicz D, Santos MCO, Simões-Lopes PC, Lailson-Brito J, Azevedo AF. Distribution and habitat characteristics of dolphins of the genus Stenella (Cetacea: Delphinidae) in the southwest Atlantic Ocean. Mar Ecol Progr Ser 2005;300:229-40.

Muir DCG, Backus S, Derocher AE, Dietz R, Evans TJ, Gabrielsen GW, Nagy J, Norstrom RJ Sonne C, Stirling I, Taylor MK, Letcher RJ. Brominated flame retardants in pola bears (Ursus maritimus) from Alaska, the Canadian Arctic, East Greenland, and Svalbard. Environ Sci Technol 2006;40:449-55.

Oigman-Pszczol SS, Figueiredo MAO, Creed JC. Distribution of benthic communities on the tropical rocky subtidal of Armação dos Búzios, Southeastern Brazil. Mar Ecol 2004;25: 173-90.

O'Shea TJ, Tanabe S. Persistent ocean contaminants and marine mammals: a retrospective overview. In: Vos JG, Bossart GD, Fournier M, O'Shea TJ, editors. Toxicology of marine mammals. London: Taylor and Francis; 2003. p. 99-134.

Pangallo KC, Reddy CM. Distribution patterns suggest biomagnification of halogenated 1'-methyl-1, 2'-bipyrroles (MBPs). Environ Sci Technol 2009;43:122-7.
Pettersson A, van Bavel B, Engwall M, Jimenez B. Polybrominated diphenylethers and methoxylated tetrabromodiphenylethers in cetaceans from the Mediterranean Sea. Arch Environ Contam Toxicol 2004;47:542-50.

Reijnders PJH, Aguilar A. Pollution and marine mammals. In: Perrin WF, Würsig B, Thewissen JGM, editors. Encyclopedia of marine mammals. San Diego: Academic Press; 2002. p. 948-57.

Santos RA, Haimovici M. Cephalopods in the diet of marine mammals stranded or incidentally caught along southeastern and southern Brazil (21-34o S). Fish Res 2001;52:99-112.

Sharma GM, Vig B. Studies on the antimicrobial substances of sponges. VI. structures of two antibacterial substances isolated from the marine sponge Dysidea herbacea. Tetrahedron Lett. 1972;17:1715-8.

Sonne C, Dietz R, Born EW, Riget FF, Kirkegaard M, Hyldstrup L, Letcher RJ, Muir DGC. Is bone mineral composition disrupted by organochlorines in East Greenland polar bears (Ursus maritimus)? Environ Health Perspect 2004;112:1711-6.

Stapleton HM, Letcher RJ, Baker JE. Debromination of polybrominated diphenyl ether congeners BDE 99 and BDE 183 in the intestinal tract of the common carp (Cyprinus carpio). Environ Sci Technol 2004;38:1054-61.

Stapleton HM, Dodder NG, Kucklick JR, Reddy CM, Schantz MM, Becker PR, Gulland F, Porter BJ, Wise SA. Determination of HBCD, PBDEs and MeO-BDEs in California sea lions (Zalophus californianus) stranded between 1993 and 2003. Mar Pollut Bull 2006;52: 522-31.

Tanabe S. PBDEs, an emerging group of persistent pollutants. Mar Pollut Bull 2004;49: 369-70.

Teuten EL, Reddy CM. Halogenated organic compounds in archived whale oil: a preindustrial record. Environ Pollut 2007;145:668-71.

Teuten EL, Xu L, Reddy CM. Two abundant bioaccumulated halogenated compounds are natural products. Science 2005;307:917-20.

Thron KU, Bruhn R, McLachlan MS. The influence of age, sex, body-condition, and region on the levels of PBDEs and toxaphene in harbour porpoises from European waters. Fresenius' Environ Bull 2004;13:146-55.

Tomy GT, Palace VP, Halldorson T, Braekevelt E, Danell R, Wautier K, Evans B, Brinkworth L, Fisk AT. Bioaccumulation, biotransformation, and biochemical effects of brominated diphenyl ethers in juvenile lake trout (Salvelinus namaycush). Environ Sci Technol 2004;38: 1496-504.

Torres JP, Lailson-Brito J, Dorneles PR, Azevedo e Silva CE, Azeredo A, Meire RO, Vidal L, Lozinski C, Azevedo AF, Malm O. Organochlorines in blubber of marine tucuxi dolphin, Sotalia guianensis, from Rio de Janeiro coastal bays, Brazil. Organohal Comp 2006;68: $580-2$.

Van de Vijver KI, Hoff PT, Das K, Van Dongen W, Esmans EL, Jauniaux T, Bouquegneau J-M, Blust R, De Coen WM. Perfluorinated chemicals infiltrate ocean waters: link between exposure levels and stable isotope ratios in marine mammals. Environ Sci Technol 2003;37: 5545-50.

Vetter W. Marine halogenated natural products of environmental relevance. Rev Environ Contam Toxicol 2006;188:1-57.

Vetter W, Stoll E, Garson MJ, Fahey SJ, Gaus C, Müller JF. Sponge halogenated natural products found at parts-per-million levels in marine mammals. Environ Toxicol Chem 2002;21:2014-9.

Voorspoels S, Covaci A, Schepens P. Polybrominated diphenyl ethers in marine species from the Belgian North Sea and the Western Scheldt estuary: levels, profiles and distribution. Environ Sci Technol 2003;37:4348-57.

Yogui, G.T.; Sericano, J.L. Polybrominated diphenyl ether flame retardants in the U.S. marine environment: a review. Environ Int. 35: 655-666.

Zhou T, Ross DG, Devito MJ, Crofton KM. Effects of short-term in vivo exposure to polybrominated diphenyl ethers on thyroid hormones and hepatic enzyme activities in weanling rats. Toxicol Sci 2001;61:76-82.

Zhu L, Hites R. Determination of polybrominated diphenyl ethers in environmental standard reference materials. Anal Chem 2003;75:6696-700. 